\title{
Odrodzenie naukowej współpracy polsko- indonezyjskiej po normalizacji stosunków dwustronnych pomiędzy Polską a Indonezją
}

\section{Rejuvenation of Cooperation in Education and Science between Poland and Indonesia after the Normalization of Bilateral Relations}

Kebangkitan Kembali Kerjasama di Bidang Pendidikan Polandia-Indonesia Pasca Normalisasi Hubungan Bilateral Antara Kedua Negara"

\author{
DR TEIJA GUMILAR, MFA, MGR DARIA ZOZULA \\ INSTYTUT JEZZYKOZNAWSTWA, UNIWERSYTET IM. ADAMA MICKIEWICZA \\ AL. NIEPODLEGŁOŚCI 4, 61-874 POZNAŃ \\ teija@amu.edu.pl, dariaz@amu.edu.pl
}

\begin{abstract}
Abstrakt
Praca opisuje jak wyglądały kontakty dydaktyczno-naukowe polsko-indonezyjskie w ujęciu diachronicznym oraz współczesnym. Metodą badawczą zastosowaną podczas prac nad niniejszą publikacją były głównie wywiady z byłymi i obecnymi stypendystami obu rządów oraz badania bibliograficzne. Po normalizacji stosunków dwustronnych w 1992r liczba Indonezyjczyków studiujących w Polsce wzrasta $\mathrm{z}$ roku na rok, czego dowodem jest również utworzenie polskiego oddziału Stowarzyszenia Studentów Indonezyjskich (Persatuan Pelajar Indonesia Polandia). Polacy to $\mathrm{z}$ kolei obecnie jedna $\mathrm{z}$ najliczniejszych grup uczestniczących w indonezyjskim programie stypendialnym Darmasiswa. Niestety brak jest wiarygodnych danych liczbowych na temat współpracy naukowej polskoindonezyjskiej przed rokiem 1992 dlatego zagadnienie wymaga dalszych badań $\mathrm{z}$ uwzględnieniem szerszego spektrum źródeł indonezyjskich.
\end{abstract}




\begin{abstract}
Abstrak
Pasca normalisasi hubungan bilateral antara Polandia dengan Republik Indonesia pada tahun 1992 dapat kita pantau perkembangan yang terjadi khususnya peningkatan kerjasama di bidang pendidikan dan sains. Masuknya Polandia menjadi anggota Uni Eropa menjadikan negara ini semakin atraktif bagi para mahasiswa asing. Jumlah mahasiswa Indonesia yang mengambil studi di Polandia bertambah dari tahun ke tahun. Fakta ini diperkuat dengan dibentuknya Persatuan Pelajar Indonesia cabang Polandia (PPI Polandia). Masyarakat Polandia juga merupakan salah satu dari grup terbesar penerima beasiswa Darmasiswa dari pemerintah Indonesia. Dalam makalah ini penulis memaparkan situasi kerjasama di bidang pendidikan dan sains pada masa sebelum dan sesudah dilakukannya pencairan hubungan bilateral serta bagaimana situasinya pada saat ini. Ulasan ini memerlukan penelitian lebih lanjut berkaitan dengan kemungkinan adanya sumber data yang lebih lengkap dari sisi Indonesia.
\end{abstract}

\begin{abstract}
Since the normalization of bilateral relations between Poland and Indonesia in 1992 we have been observing a steady growth, particularly in the educational and scientific cooperation between thw two countries. The accession of Poland to the European Union have made this country a more attractive destination for foreign students. The number of Indonesians studying in Poland increases year over year. This fact is strengthened through the establishment of Indonesian Students Association in Poland (PPI Polandia). Polish citizens are among largest groups of Darmasiswa recipients - a scholarship program provided by the Indonesian government. In this paper the authors trace the records of cooperation in the field of education and science during the eras before and after the normalization of bilateral relations of both countries as well as the situation observed in recent years. This issue needs further exploration regarding the possibility of more data available in Indonesian sources of records.
\end{abstract}

\title{
Wprowadzenie
}

Rok 1955 był przełomowym rokiem dla akademickich kontaktów polskoindonezyjskich. W tym roku Republika Indonezji pod wodzą pierwszego 
dr Teija Gumilar, mgr Daria Zozula: Odrodzenie naukowej wspótpracy polsko-indonezyjskiej po normalizacji stosunków dwustronnych ...

prezydenta, pro-socjalistycznego Sukarno zacieśniła stosunki z krajami tzw. bloku wschodniego, m.in. z Polską, Czechosłowacją, Jugosławią i NRD. W ramach porozumienia $\mathrm{z}$ Polską Republiką Ludową podpisano umowy o współpracy $\mathrm{w}$ dziedzinach technologii i edukacji, na mocy których na polskie uniwersytety i politechniki przyjęto indonezyjskich studentów a do Indonezji wysłano specjalistów-inżynierów mających doświadczenie w wielu dziedzinach przemysłu. Po obaleniu rządów Sukarno i likwidacji Partai Komunis Indonesia (Komunistycznej Partii Indonezji) w roku 1965 stosunki dyplomatyczne zerwano. Dopiero po normalizacji stosunków dyplomatycznych 6 października 1992 oba kraje ponownie zaczęły mozolnie na nowo odkrywać możliwości współpracy, w tym również współpracy naukowej.

\section{Współpraca na polu naukowym w okresie Orde Lama}

W okresie rządów Sukarno, obecnie nazywanym Orde Lama (ind. „stary porządek"), Indonezja pozostawała pod silnym wpływem kontrowersyjnej ideologii NASAKOM ${ }^{1}$, łączącej teoretycznie sprzeczne ze sobą ideały takie jak socjalizm, skrajny nacjonalizm oraz kult religijny. Praktycznie przyjęcie Nasakomu jako ideologii państwowej pozwoliło połączyć wywodzące się z praw zwyczajowych elementy (np. starszyzna wsi została formalnie włączona do administracji państwowej) z zasadami socjalistycznymi (wzajemna pomoc obywatelska) i nacjonalistycznymi (podkreślanie jedności narodu przy jednoczesnym bagatelizowaniu pochodzenia etnicznego) ${ }^{2}$.

Pomimo wyraźnego sympatyzowania z krajami ZSRR, w roku 1955, podczas organizowanej w Bandungu konferencji krajów pokolonialnych (nazywanej Konferensi Asia-Afrika), w której udział wzięli przedstawiciele 29 krajów reprezentując ponad połowę ówczesnej populacji Ziemi, Sukarno zadeklarował neutralność Indonezji w stosunku do krajów Bloku Wschodniego i Bloku Zachodniego i odmówił udziału Indonezji w tak zwanej Zimnej Wojnie. Umożliwiło to utrzymanie dobrych stosunków z państwami obu frakcji, a co za tym idzie nawiązanie stosunków dyplomatycznych oraz podpisanie korzystnych umów handlowych i porozumień o współpracy międzynarodowej.

Jak już wspomniano, Polska nawiązała stosunki dyplomatyczne z Indonezją w 1955, jednakże dopiero w 1960 rozpoczęła pracę ambasada Indonezji p. Adama Malika w Warszawie.

Jeśli chodzi o współpracę w dziedzinie edukacji, wydarzeniem, które zainaugurowało współpracę pomiędzy tymi dwoma krajami było sprowadzenie do Polski w 1956 r. prof. Bakri Siregara, który prowadził przez dwa semestry zajęcia z języka i kultury indonezyjskiej na Uniwersytecie Warszawskim. Również w 1956 do Indonezji został wysłany pewien polski student3 aby nauczyć się języka indonezyjskiego. Następnie, 13 lutego 1957 r. do Polski przybyła grupa

\footnotetext{
1 Akronim utworzony od pierwszych liter słów nasionalisme (nacjonalizm), agama (religia) oraz komunisme (komunizm)

${ }^{2}$ Ricklefs, M. C. (1991). A History of Modern Indonesia since c. 1300 (2 ed.). MacMillan. p. 268

3 Nie dotarliśmy do jego nazwiska. - T.G. D.Z.
} 
dziesięciu studentów indonezyjskich. Studentom wolno było wybrać dowolny kierunek z kierunków inżynieryjnych (np. Mechanika Energetyki i Lotnictwa) na Politechnice Warszawskiej4. W okresie od 1955 do 1965 dziesiątkom studentów indonezyjskich przyznano stypendia na polskich uczelniach. Pan Pandji Garma, jeden ze studentów indonezyjskich studiujących w Polsce wspomina, że zanim studentom pozwolono uczestniczyć w zajęciach musieli wziąć najpierw udział w kursie języka polskiego. Uniwersytety, które w latach 1955-1965 przyjęły indonezyjskich studentów to: Uniwersytet Warszawski, Politechnika Warszawska, Uniwersytet Łódzki, Uniwersytet Gdański.

Kwoty stypendiów otrzymywanych przez studentów to: (i) 5000 zł jednorazowo otrzymane od rządu indonezyjskiego, (ii) $1000 \mathrm{zt} /$ miesiąc przez cały okres studiów od rządu polskiego, (iii) pokrycie kosztów nauki idarmowe zakwaterowanie w domach akademickich5.

Brak jest szczegółowych danych ilu studentów dokładnie zostało wysłanych z Indonezji do Polski. Pan Sugiyanto Darmonegoro szacuje, że mogło ich być około pięćdziesięciu. Wiadomo jednak, że nie wszyscy z nich ukończyli edukację w Polsce, kilku po rozpoczęciu studiów w Polsce, przerywało je i kontynuowało $\mathrm{w}$ innych krajach europejskich, kilku innych wróciło przed uzyskaniem dyplomu do Indonezji głównie z powodów politycznych. Do dziś w Polsce żyje 6 byłych stypendystów z tamtego okresu, którzy w Polsce osiedlili się i założyli rodziny. Warty wspomnienia jest również fakt przyznania Sukarno tytułu doktora Honoris Causa Uniwersytetu Warszawskiego w dziedzinie prawa i polityki dnia 30 kwietnia 1959 (jako promotor wystąpił prof. Manfred Lachs. Równocześnie z zawiązaniem umowy na polu naukowym rozpoczęto również intensywną współpracę $\mathrm{w}$ dziedzinie przemysłu. Polska w ramach pomocy w rozwinięciu kluczowych gałęzi przemysłu Indonezji wysłała na tereny Nusantary wielu specjalistów, m.in. inżynierów lotnictwa oraz stoczniowców. Umowa o współpracy na polu rozwoju lotnictwa indonezyjskiego pomiędzy rządami obu państw podpisana w $1961 \mathrm{r}$., zaowocowała powstaniem 44 samolotów WILGA/ind. Gelatik. Polscy inżynierowie zostali wysłani do Indonezji, by nadzorować budowę linii produkcyjnej oraz szkolić pracowników w zakładach Nurtanio w Bandungu . Z pomocą polskich naukowców udoskonalono również indonezyjskie systemy radarowe używane w nawigacji oraz zbudowano fabrykę cukru trzcinowego na Sumatrze.

\section{Upadek rządów Sukarno i przerwanie współpracy pomiędzy Polską a Indonezją.}

W nocy z 30 września na 1 października 1965 r. komunistyczna partia PKI, próbowała przeprowadzić zamach stanu. Zamach został udaremniony przez Armię Indonezyjską pod wodzą generała Suharto, w rezultacie czego w pierwszych tygodniach października rozwiązano PKI oraz wszystkie organizacje robotnicze w Indonezji a rząd prezydenta Sukarno został obalony. Od 500 tysięcy do $2 \mathrm{mln}$ obywateli Indonezji, którzy należeli do PKI lub

\footnotetext{
4 Na podstawie wywiadu z p. Sugiyanto Darmonegoro 20.06.2016r.

5 Garna,P. 2006: Polska Perkembangan Pilitik Ekonomi Dan Sosial Budaya Dari Pengalamanku, Primaco Akademika, Bandung 2006
} 
dr Teija Gumilar, mgr Daria Zozula: Odrodzenie naukowej wspótpracy polsko-indonezyjskiej po normalizacji stosunków dwustronnych ...

choćby byli zwolennikami myśli komunistycznej zostało zamordowanych. Kolejny milion został uwięziony a na rodziny członków PKI spadły brutalne sankcje, m.in. zakaz pełnienia funkcji publicznych aż do 3 pokolenia w przyszłość. To ludobójstwo wywołało stanowczy sprzeciw krajów socjalistycznych na całym świecie. Po oficjalnym objęciu władzy przez Suharto Indonezja stała się krajem antykomunistycznym a stosunki z krajami socjalistycznymi uległy znacznemu pogorszeniu.

Dramatyczne wydarzenia w kraju miały zły wpływ na sytuacje indonezyjskich studentów studiujących w krajach socjalistycznych. Wielu $\mathrm{z}$ nich wezwano do powrotu do Indonezji. Wszyscy indonezyjscy studenci, którzy nadal mieszkali w Polsce musieli przejść test przekonań politycznych, który miał określić czy są oni zwolennikami komunizmu czy jego przeciwnikami. Tym, którzy nie popierali polityki Orde Baru, jak były nazywane rządy generała Suharto, odebrano paszporty i obywatelstwo indonezyjskie. Wielu $\mathrm{z}$ nich odtąd aktywnie działo na arenie międzynarodowej jako przeciwnicy nowego reżimu.

Studentom, którzy poparli nowego prezydenta pozwolono kontynuować studia w Polsce, jednakże spotkali się oni z różnego rodzaju represjami tym razem ze strony polskiej, również na uniwersytecie. Pandji Garta wspomina, że nie dopuszczano ich do egzaminów z języka polskiego kończącego roczną naukę i kazano powtarzać kurs, nie przedłużano im wizy oraz byli obserwowani przez służby bezpieczeństwa ${ }^{6}$. Studenci, którym nowy rząd indonezyjski odebrał obywatelstwo nie mogli powrócić do ojczyzny. Stało się to możliwe dopiero po upadku rządów Suharto w roku 1998. Wielu z nich osiedliło się wiec w Polsce gdzie założyli rodziny lub wyjechało do innych krajów europejskich.

\section{Kontakty indonezyjsko-polskie w okresie zamrożenia współpracy 1966-1992}

W przeciągu kolejnych 20 lat wymiana studencka polsko-indonezyjska znacznie się zmniejszyła.

Z Polski najliczniejszą grupą, która została wysłana do Indonezji byli księża misjonarze werbiści, przybyli do Indonezji 27 sierpnia 1965 r.7 na misje głównie na wyspę Flores, pełna lista nazwisk pierwszych polskich misjonarzy werbistów:

1. Stanisław Wyparło,

2. Tadeusz Gruca,

3. Sylwester Pająk,

4. Stanis Mucek,

5. Czesław Osiecki,

6. Józef Błoch,

7. Jan Kozłowski,

8. Stefan Wrosz,

${ }^{6}$ Garna, P:, Polska Perkembangan Pilitik Ekonomi Dan Sosial Budaya Dari Pengalamanku, Primaco Akademika, Bandung 2006;24

7 Na podstawie relacji księdza p. Glinki SVD 


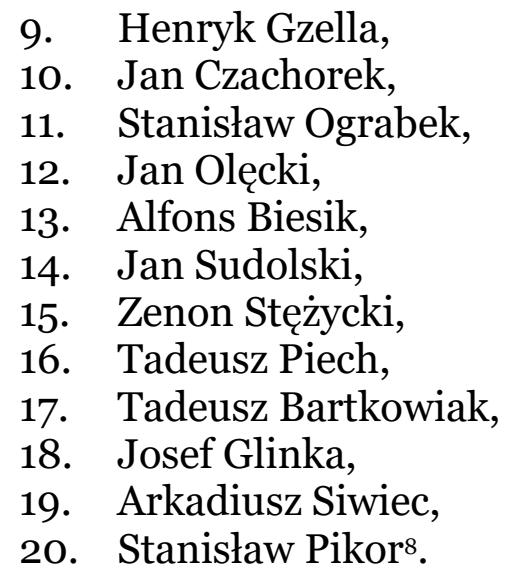

Kilku misjonarzy werbistów nadal pracuje i mieszka w Ledalero na tej wyspie. W Indonezji pracują obecnie poza werbistami równiez misjonarze z innych zgromadzeń: sercanie, salezjanki i klarentynki ${ }^{9}$

Pomimo oficjalnego zamrożenia stosunków dyplomatycznych, zainteresowanie Indonezją w Polsce nie malało, na przestrzeni 26 lat w Polsce ukazało się około ${ }^{10}$ stu publikacji związanych z Indonezją, w tym monografie na temat sytuacji politycznej (...) wiele przekładów legend i bajek indonezyjskich (w tłumaczeniu Roberta Stillera) oraz wiele monografii i artykułów podróżniczych.

Brak szczegółowych informacji na temat publikacji związanych z Polską w Republice Indonezji w tym okresie, wiadomo jednak, że Indonezyjczycy żywo zainteresowali się Polską w 1989 r. razem ze wzrostem popularności ruchu Solidarność, która „była inspiracją Indonezyjczyków do odejścia od systemu autokratycznego"11. Wiele popularnych czasopism młodzieżowych w tamtym okresie publikowało tłumaczenia najpopularniejszych piosenek angielskich wraz z wyjaśnieniami dotyczącymi okoliczności powstania utworu.

\section{Normalizacja stosunków dyplomatycznych pomiędzy Polską a Indonezją.}

W trzy lata po normalizacji stosunków dyplomatycznych pomiędzy Polską a Indonezją strona indonezyjska wystąpiła z propozycją przywrócenia współpracy $\mathrm{w}$ zakresie edukacji. Polskim studentom zaproponowano uczestnictwo w programie Darmasiswa w 1995 r. Pierwszą stypendystką z Polski była obecna muzykolog Marzanna Popławska. W kolejnych latach,

\footnotetext{
8 http://provinsisvdende.weebly.com/blog-berita/50-tahun-misionaris-polandia

9 Na podst. Wywiadu z konsulem polskiej ambasady w Dżakarcie, p. Maciejem Duszyńskim,

10 Brak szczegółowych danych za lata 1989-1992, spisu bibliograficznego publikacji dotyczących Indonezji na przestrzeni 1913-2013r. dokonał Klimiuk w Bibliografia polskich $i$ polskojęzycznych publikacji z zakresu studiów indonezjanistycznych i malaistycznych (1913-2013) [w]: Piotr Bachtin, Maciej Klimiuk (red.), Azja i Afryka: inność - odmienność - różnorodność,Wydział Orientalistyczny, Uniwersytet Warszawski, Warszawa 2014:209-232

11 Maciej Duszyński, http://toronto-magazyn.pl/miasto/item/544-o-polakach-w-indonezji-itorunskich-akcentach-w-muzulmanskim-kraju

maciej duszyński konsul polskiej ambasady w jakarcie (dat dostępu 10.12.2016)
} 
dr Teija Gumilar, mgr Daria Zozula: Odrodzenie naukowej wspótpracy polsko-indonezyjskiej po normalizacji stosunków dwustronnych ...

zwłaszcza po roku 2000, w związku z intensywną promocją programu stypendialnego Darmasiswa przez Ambasadę Republiki Indonezji w Polsce oraz zacieśnieniu się kontaktów biznesowych pomiędzy tymi dwoma krajami każdego roku w programie Darmasiswa brało udział nawet kilkudziesięciu studentów z Polski:

$>$ Rok akademicki 2001/2002 4

$>$ Rok akademicki 2002/2003 1

$>$ Rok akademicki 2003/2004 5

$>$ Rok akademicki 2004/2005 4

$>$ Rok akademicki 2005/2006 7

$>$ Rok akademicki 2006/2007 13

$>$ Rok akademicki 2007/2008 27

$>$ Rok akademicki 2008/2009 7

$>$ Rok akademicki 2009/2010 10

$>$ Rok akademicki 2010/2011 45

$>$ Rok akademicki 2011/2012 67

$>$ Rok akademicki 2012/2013 40

$>$ Rok akademicki 2013/2014 26

$>$ Rok akademicki 2014/2015 30

> Rok akademicki 2015/2016 28

$>$ Rok akademicki 2016/2017 37

> Lącznie uczestników: $\quad 351$

Nie bez wpływu pozostają tu również międzyuniwersyteckie umowy podpisywane na przestani kilkunastu lat:

1. Persetujuan Antara Pemerintah Republik Polandia dan Pemerintah Republik Indonesia tentang Kerjasama Kebudayaan dan Pendidikan, 24 April 2003.12 (Porozumienie pomiędzy rządami RP oraz RI o współpracy na polu kultury i edukacji, podpisane 24 kwietnia 2003 r.)

2. Protokol tentang Pertukaran Kebudayaan dan Pendidikan antara Pemerintah Republik Polandia dan Pemerintah Republik Indonesia untuk Tahun 2008-2011, 8 Mei 2008 (Protokół o wymianie kulturowoedukacyjnej pomiędzy rządami RP i RI na lata 2008-2011 podpisany 8 maja 2008).

3. Pernyataan Kehendak untuk Kerjasama di Bidang Pendidikan Tinggi antara Kementerian Pendidikan dan Kebudayaan Republik Indonesia dengan Kementerian Ilmu Pengetahuan dan Pendidikan Tinggi Republik Polandia, 4 September 2013. (Oświadczenie o zamiarze współpracy w zakresie szkolnictwa wyższego pomiędzy indonezyjskim i polskim Ministerstwami Edukacji, podpisane w dniu 4 sierpnia 2013 r.)

\footnotetext{
12 Przy okazji wizyty prezydent Republiki Indonezji, Megawati Soekarnoputri w Warszawie.
} 
Należy tu również wspomnieć o polskich inicjatywach promocji kultury indonezyjskiej i kształceniu muzykologów, etnologów czy językoznawców związanych z Indonezją.

„Na początku lat 1990-tych Ambasada RI nawiązała współpracę z Instytutem Muzykologii UW, dzięki której rozpoczęła działalność istniejąca do dziś warsztatowa grupa gamelanowa (ok. 30 studentów rocznie). Zajęcia z muzykami prowadzili kolejno: Soegiyanto (stały konsultant), dr Marzanna Popławska, dr Tomasz Nowak, mgr Dawid Martin, mgr Tomasz Matlingiewicz, mgr Marta Kramicz, mgr Maria Szymańska-Ilnata. Z grupy warsztatowej wyłoniła się złożona $\mathrm{z}$ aktualnych studentów i absolwentów Instytutu Warszawska Grupa Gamelanowa, będąca już nie tylko grupą warsztatową, ale pierwszym i jedynym tego typu zespołem muzycznym w Polsce. [...]Obecnie opiekunem grupy jest mgr Dawid Martin,"13

W 2004 roku na uniwersytecie im. A. Mickiewicza w Poznaniu w ramach 5 letnich studiów magisterskich na kierunku etnolingwistyka otworzono specjalność indonezyjską, w ramach której studentom oferowano ponad 720 godzin lektoratu języka indonezyjskiego. Specjalność tę rozpoczęło 17 osób a 12 ukończyło. W roku 2009 UAM otworzył kierunek filologia indonezyjsko-malajska, z językiem indonezyjskim jako głównym językiem. W ramach studiów licencjackich i magisterskich studenci zdobywają wiedzę na temat języka, kultury, literatury i historii Indonezji.

Poza programem Darmasiwa wymiany studentów odbywają się również na mocy porozumień między uniwersyteckich. Obecnie uniwersytety które podpisały MOU to m. in.:

> Uniwersytet im. Adama Mickiewicza z Universitas Padjajaran, od roku 2006.

$>$ Uniwersytet im. Adama Mickiewicza z Universitas Pasundan, od roku 2008.

$>$ Uniwersytet im. Adama Mickiewicza z Universitas Sriwijaya, od roku 2013.

> Uniwersytet Warszawski z Institut Teknologi Bandung, od roku 2012.

> Politechnika Warszawska z Institut Teknologi Bandung, od roku 2012.

Programy stypendialne w których mogą uczestniczyć studenci z Polski i Indonezji to między innymi:

$>$ Darmasiswa (od 1995r) - program Ministerstwa Edukacji I kultury Indonezji który oferuje możliwość studiowania od 1 do 2 semestrów w ramach specjalnych kursów interesującego beneficjenta zagadnienia m. in.: języka, tańca czy muzyki tradycyjnej, fotografii czy historii Indonezji na wybranej przez niego uczelni. Ministerstwo oprócz kosztów nauki stypendysty zapewnia mu także kieszonkowe.

> Stypendium Sztuka i kultura (Seni dan Budaya od 2011) - program Ministerstwa Spraw Zagranicznych RI oferujący krótkie, trzymiesięczne kursy na temat szeroko pojętej kultury i sztuki indonezyjskiej w kilku ośrodkach kulturowych.

\footnotetext{
13 http://www.imuz.uw.edu.pl/index.php/pl/studenci/warsztatowy-zespol-gamelanowy
} 
dr Teija Gumilar, mgr Daria Zozula: Odrodzenie naukowej wspótpracy polsko-indonezyjskiej po normalizacji stosunków dwustronnych ...

Stypendium oferowane przez Ministerstwo Religii RI skierowane do muzułmanów będących obywatelami polski którzy chcą poznać indonezyjski odłam islamu. (od 2011)

- Erasmus Mundus (od 2012) - program europejski dla studentów oferujący wymiany studenckie pomiędzy krajami unii europejskiej i krajów spoza UE.

Stypendium im. Ignacego Łukasiewicza (od 2015) skierowane do studentów z krajów rozwijających się (w tym Republiki Indonezji), chcących podjąć w Polsce studia magisterskie lub doktoranckie. W ramach programu oferowane są stypendia na bezpłatne studia II stopnia (poprzedzone rocznym kursem przygotowawczym do podjęcia nauki w Polsce) oraz na studia III stopnia prowadzone w uczelniach publicznych nadzorowanych przez ministra właściwego do spraw szkolnictwa wyższego (lista uczelni pod poniższym linkiem). Wysokość stypendium, z którego opłacane są koszty zakwaterowania i utrzymania wynosi 1350 PLN miesięcznie. Podczas pierwszej edycji programu stypendialnego na rok 2014/2015 przyjęto 46 stypendystów, z czego aż 57\% (26 osób) stanowili obywatele Republiki Indonezji.

Ponadto w $2011 \mathrm{r}$. indonezyjskie Ministerstwo Edukacji rozpoczęło program darmowych trzymiesięcznych kursów języka indonezyjskiego, prowadzony $\mathrm{w}$ ambasadzie Republiki Indonezji $\mathrm{w}$ Warszawie oraz w zainteresowanych ośrodkach uniwersyteckich. Uniwersytety, które wzięly udział w programie to:

1. Uniwersytet Warszawski

2. Uniwersytet im. Mikołaja Kopernika, Toruń

3. Szkoła Głowna Handlowa, Warszawa

4. Collegium Civitas, Warszawa

W Indonezji jak dotąd jedynym uniwersytetem gdzie nauczano języka indonezyjskiego jest Universitas Indonesia $\mathrm{w}$ Dżakarcie (pierwszy raz w 2011r. w formie semestralnego fakultetu oraz w 2014r. jako całoroczny fakultet na kierunku Sastra Russia). W 2013r. Universitas Indonesia stał się beneficjentem Międzynarodowego Funduszu Wyszehradzkiego, który ma na celu rozwinięcie współpracy również na polu naukowym pomiędzy krajami spoza Europy z tak zwanymi krajami grupy wyszehradzkiej (Republika Czeska, Republika Słowacka, Republika Węgierska i Rzeczpospolita Polska), co $\mathrm{w}$ przyszłości może zaowocować współpracą naukową pomiędzy UI a jednym z polskich uniwersytetów. Liczba studentów indonezyjskich którzy podejmują studia $\mathrm{w}$ Polsce $\mathrm{z}$ roku na rok wzrasta. Są oni w większości stypendystami programów rządowych lub uczestnikami wymian studenckich będących częścią umów międzyuniwersyteckich. Według danych Stowarzyszenia Studentów Indonezyjskich w Polsce (Persatuan Pelajar Indonesia), w czerwcu 2016 w Polsce studiowało trzydziestu Indonezyjczyków w 6 ośrodkach uniwersyteckich z , czego 26 to stypendyści stypendium im. Łukasiewicza. W kolejnych latach przewiduje się zwiększenie liczby studentów pochodzenia indonezyjskiego w Polsce, ze względu na duży 
wzrost zainteresowania ośrodkami naukowymi wśród młodzieży indonezyjskiej chcącej podjąć studia w Europie. ${ }^{14}$

\section{Zakończenie}

Zagadnienie współpracy na polu naukowym pomiędzy Rzeczpospolitą Polską a Republiką Indonezji wymaga niewątpliwie dalszych gruntownych badań. diachronicznych i uważnego monitorowania stanu obecnego. Pomimo zamrożenia stosunków bilateralnych pomiędzy obydwoma krajami na okres prawie 30 lat współpraca naukowa trwała nadal jednakże dostęp do informacji na ten temat jest ograniczony. Po roku 2000 można zauważyć ciągły wzrost liczby studentów uczestniczących w stypendiach i wymianach międzyuniwersyteckich oraz wzrost liczby podpisanych umów międzyuczelnianych o współpracy.

\section{Bibliografia}

Klimiuk M. Bibliografia polskich i polskojęzycznych publikacji z zakresu studiów indonezjanistycznych i malaistycznych (1913-2013) [w]: Bachtin, Klimiuk (red.), Azja i Afryka: inność - odmienność - różnorodność, Wydział Orientalistyczny, Uniwersytet Warszawski, Warszawa 2014:209-232

Ricklefs, M. C. (1991). A History of Modern Indonesia since c. 1300 (2 ed.). MacMillan. p. 268

Garna, P., Polska Perkembangan Pilitik Ekonomi Dan Sosial Budaya Dari Pengalamanku, Primaco Akademika, Bandung 2006

Ograbek, S. 5o-lat na Wyspach Flores i Borneo, Zakład Poligraficzny Henryk Górowski, Piła 2012

\section{Źródła internetowe}

http://sourcebooks.fordham.edu/halsall/mod/1955sukarno-bandong.html (data dostępu 20 czerwca 2016r.)

http://www.kronikarp.pl/szukaj,28376,tag-689418,strona-5 (data dostępu 20 czerwca 2016r.)

http://www.uw.edu.pl/uniwersytet/historia/doktoraty-honorowe/(data dostępu 20 czerwca 2016r.)

https://sanzpermana2013.wordpress.com/38-2/(data dostępu 20 czerwca 2016r.)

http://www.imuz.uw.edu.pl/index.php/pl/studenci/warsztatowy-zespol-gamelan owy (data dostępu 20 czerwca 2016r.)

http://toronto-magazyn.pl/miasto/item/544-o-polakach-w-indonezji-i-torunskich - akcentach -w-muzulmanskim-kraju (dat dostępu 10.12.2016)

http://sourcebooks.fordham.edu/halsall/mod/1955sukarno-bandong.html (data dostępu 20 czerwca 2016r.)

http://provinsisvdende.weebly.com/blog-berita/50-tahun-misionaris-polandia (data dostępu 20 czerwca 2016r.)

${ }^{14} \mathrm{Na}$ podstawie wywiadu przeprowadzonego z p. Abdurrachmanem Niarmanem, przewodniczącym PPI Polandia (dnia. 20 czerwca 2016r.) 